\title{
IAMJ
}

INTERNATIONAL

AYURVEDIC

MEDICAL JOURNAL

\section{FOCUS ON HEALTH BENEFITS OF TAMBUL SEVAN VIDHI AS DINCHARYA UPAKRAMA - A LITERATURE REVIEW}

\author{
Shradha Venkatrao Joshi ${ }^{1}$, Shital O. Chavan ${ }^{2}$ \\ ${ }^{1}$ PG Scholar, Department of Swasthavritta and Yoga, Government Ayurveda College, Nanded, Maharashtra, India \\ ${ }^{2}$ Associate Professor, Department of Swasthavritta and Yoga, Government Ayurveda College, Nanded, \\ Maharashtra, India
}

Corresponding Author: joshisv92@gmail.com

https://doi.org/10.46607/iamj1809122021

(Published Online: December 2021)

Open Access

(C) International Ayurvedic Medical Journal, India

Article Received: 10/11//2021 - Peer Reviewed: 28/11/2021 - Accepted for Publication 29/11/2021

\section{Check for updates}

\begin{abstract}
In Ayurveda classics, there is a detailed explanation of what a person should practice from getting up early in the morning to sleeping at night under dincharya upakrama. Tambul Sevan (chewing betel leaf) is described as one of the dincharya upakram i.e., daily regimen. Tambul Sevan means chewing betel leaf mixed with betel nut and other aromatic herbs. Tambul Sevan is an important social component. In Indian tradition, Tambul or paan has been consumed from vedic era that is 5000 years ago. But nowadays the traditional betel leaf and betel nuts are replaced by tobacco and other masala paan. Therefore, the whole concept of Tambul Sevan and its usefulness has been changed. Now there is a need to understand what Tambul Sevan Vidhi is. Ayurveda says Tambul Sevan maintains good oral hygiene and good taste of mouth, it also prevents bad odour and other oral cavity diseases. Tambul Sevan maintains agni (digestive fire) at its samya avastha (normal condition), so it is said to be consumed at end of the meal i.e., bhojananate tambul sevan. Here, this review article highlights the traditional way of Tambul Sevan Vidhi and its health benefits briefly.
\end{abstract}

Keywords: Tambul, Tambul Sevan Vidhi, betel leaf, dincharya, health benefits. 


\section{INTRODUCTION}

Ayurveda has explained daily regime and seasonal regime in context with Ahara and Vihara for a healthy lifestyle. Tambul Sevan is also one of the daily regiments which has its promotional and preventive benefits. In Indian culture betel leaves and areca nuts are used on special occasions like puja, home havan, marriage and other auspicious occasions. According to Ayurveda Tambul Sevan is post-meal digestive stimulant oral deodorant natural antiseptic mood elevator aphrodisiac. ${ }^{1}$ Betel leaf is useful for the treatment of various diseases like bad breath, boils and abscesses conjunctivitis, constipation, headache, hysteria, itching, mastitis, swelling of gums, ringworm, rheumatism, abrasion, cuts and injuries etc as folk medicine while the root is known for its female contraceptive effects. ${ }^{2}$ Nowadays using masala paan containing tobacco is trending in the society which has harmful effects on the body. There is the necessity of people being aware of the health benefits of Tambul Sevan with proper methods and rules.

Aim: Review on health benefits of Tambul Sevan Vidhi

\section{Materials and Method}

Ayurveda texts like Charaka Samhita, Sushruta Samhita, Ashtanga Sangraha, Bhavprakasha, Kaiyyadev Nighantu were referred for study. Some online websites and articles were also referred to for this study. Discussion and conclusion are based on this whole study.

\section{Review of literature}

Tambul

Tambul Sevan is eating betel leaf (paan) mixed with areca nuts and other aromatic mouth cleansing herbs.

Table 1: Tambul dravya ${ }^{3-7}$

\begin{tabular}{|c|c|c|c|c|c|c|}
\hline Sr.No. & Dravya/Content & $\begin{array}{l}\text { Charaka } \\
\text { Samhita }\end{array}$ & $\begin{array}{l}\text { Sushruta } \\
\text { Samhita }\end{array}$ & $\begin{array}{l}\text { Ashtanga } \\
\text { Sangraha }\end{array}$ & $\begin{array}{l}\text { Bhavprakasha } \\
\text { Samhita }\end{array}$ & $\begin{array}{l}\text { Kaiyyadev } \\
\text { Nighantu }\end{array}$ \\
\hline 1 & $\begin{array}{l}\text { Jatiphal } \\
\text { (Myristica fragrans) }\end{array}$ & + & + & + & + & + \\
\hline 2 & $\begin{array}{l}\text { Kankol } \\
\text { (Piper cubeba) }\end{array}$ & + & + & + & - & + \\
\hline 3 & $\begin{array}{l}\text { Karpur Niryasa } \\
\text { (Cinnamomum Camphora) }\end{array}$ & + & + & + & + & + \\
\hline 4 & $\begin{array}{l}\text { Katuka } \\
\text { abelmoschus) }\end{array}$ & + & + & + & - & + \\
\hline 5 & $\begin{array}{l}\text { Lavanga } \\
\text { (Syzygiumaromaticum) }\end{array}$ & + & + & + & + & + \\
\hline 6 & Puga phal (Areca catechu) & + & + & + & + & + \\
\hline 7 & $\begin{array}{l}\text { Sukshma Ela } \\
\text { (Elletariacardamonum) }\end{array}$ & + & - & - & - & - \\
\hline 8 & $\begin{array}{l}\text { Churna } \\
\text { (Slaked lime) }\end{array}$ & - & + & + & + & + \\
\hline 9 & Khadira (Acacia catechu) & _- & _- & + & + & + \\
\hline 10 & Kasturi (Musk) & - & - & _- & + & _- \\
\hline
\end{tabular}

Table 2: Method of preparation of Tambul as mentioned in Ayurvedic texts ${ }^{8}$

\begin{tabular}{|l|l|l|}
\hline Sr.No. & Dravya & Quantity \\
\hline 1 & Tambul patra & 2 \\
\hline 2 & Puga phal & 1 \\
\hline 3 & Churna & Little bit \\
\hline 4 & Khadira & Little bit \\
\hline
\end{tabular}


This is the basic tambul preparation method. One can add other ingredients listed above, according to their taste.

Betel leaf and areca nut should be in the same proportion so that tabmul gives good colour. If there are more areca nuts, it will not give good colour, if slaked lime is more then it will give a bad odour and if betel leaves are more it will be more aromatic.

Table 3: Acharya Kaiyyadev, has mentioned which ingredient should be more in proportion with respect to time. ${ }^{9}$

\begin{tabular}{|l|l|l|}
\hline Sr.No. & Dravya in more proportion & Time \\
\hline 1 & Puga phal & Morning \\
\hline 2 & Churna & Afternoon \\
\hline 3 & Tambul patra & Night \\
\hline
\end{tabular}

If Khadira is added in more proportion Tambul gains properties like mouth cleanser, hygiene, good appetizers, delectable taste and prevents urinary tract diseases and diabetes. ${ }^{10}$

While eating Tambul one should exclude the tip, root, and middle part of the betel leaf. In Ayurveda it is said that life $(a a y u)$ resides on the tip, reputation(yasha) at roots and wealth (Laxmi) at the middle portion of the leaf. So, if one eats tip, it gives rise to sin, root gives rise to disease and middle part takes away life and veins ( sira) of leaf destroys intelligence. ${ }^{11}$

While chewing tambul the first-time juice secreted is similar to poison, second-time juice is hard for digestion and purgative and third time onwards tambul juice is similar to nectar (amruttulya). Therefore, while eating Tambul first two-time juice should be spit out and swallowing should be from the third time onwards. $^{12}$

\section{Proper time for Tambul sevan ${ }^{13}$}

After Ajana Karma, Nasya Karma, Gandusha, Dhumpana, after getting out of sleep, after meals, after vomit, while indulging in sexual acts, in the assembly of the king and wise people.

\section{Indications $^{14}$}

Alasa (abscess at the route of the tongue), Upjivika (ranula), Vidhradhi (abscess), Talu shosha (dryness of palate), Dantaroga (diseases of teeth), Arbuda (tumour), Galaganda (goitre), Apachi (enlargement of glands of the neck) and other Kapha Dosha disorder

\section{Contra indications ${ }^{15}$}

Bleeding disorder, dryness, eye disorders, intoxication, coma, unconsciousness, poisoning, burning, alcoholics.
Excessive (in proportion and frequency) Tambul $\operatorname{sevan}^{16}$

Decreases strength of eyes and body. Weakens teeth, hairs, ear, body complexion and colour and body strength.

\section{Health benefits ${ }^{17}$}

Tambul has a bitter, sweet, pungent, astringent taste and it is alkaline (ksharyukta).

Tambul wards off excessive Kapha Dosha and controls Vata Dosha. It kills microorganisms, removes odour of mouth and keeps it clean

Tambul provides lustre and charm on the face, provides good quality voice, removes dirt out of jaw and teeth, controls excessive saliva.

Acharya Yoga Ratnakar said that these properties of tambul are rare in heaven.

\section{Harmful effects of paan masala ${ }^{18}$}

Nowadays traditional tambul has been replaced by paan masala. Paan masala is widely available across all strata of society. It is carcinogenic, genotoxic, and has harmful effects on the oral cavity, liver, kidney, and reproductive organs.

\section{DISCUSSION}

Betel leaf has tikta (bitter) and katu (pungent) rasa (taste), katu (pungent) vipaka (taste conversion after digestion), ushna (hot) virya (potency) ${ }^{19}$. Due to these properties betel leaf wards off excessive kapha and provides good taste and smell in the mouth. It improves taste, strength, voice, it is mild purgative, it is carminative in nature. Betel leaf is a cheap and naturally available appetizer. Everyone, despite their financial condition, can afford this natural appetizer on 
a regular basis. Besides this, it is an easy to administer and nonhazardous method of maintaining oral health. When betel leaf is mixed with other ingredients mentioned in Tambul preparation it becomes a digestive stimulant and mouth cleanser. It alleviates all doshas and is beneficial for oral and overall health.

Tambul is said to have vashya property which means it can make people agree to you, that is why maybe it is used in auspicious occasions like marriage, home, havan, pooja. It opens up conversation and could bring peace and comfort to the community.

\section{Result}

Thus, it can be said that proper Tambul Sevan does not only have health benefits but also it helps in maintaining comfort, connectedness and wellbeing in society.

\section{CONCLUSION}

Tambul Sevan has many health benefits when used in proper proportion and by preparing by proper method. Nowadays tobacco has taken place in Tambul Sevan and in the form of masala paan, which has harmful effects and carcinogenic effects on the body.

\section{REFERENCES}

1. Shrishailappa Badami, Sujaya R, Rai Suresh B In vitro antioxidant properties of Indian traditional paan and its ingredients. Indian Journal of traditional knowledge April 2004.

2. Khana S Paanvittiksilpakendra Betel leaf-based industry Nabanna Bharati 1997302.169

3. Vd. Y. G. Joshi.Charak Samhita vol 1 fourth edition, Vaidyamitra publication, Pune, India, Sutrasthan 5/76 92-93.

4. Ambika Dutt Shastri Sushrut Samhita vol 1, reprint 1994 Chaukhamba publication, Varanasi, India, Chikitsa Sthana 24/21 288.

5. Sharma Shiv Prasad Ashtanga Sangraha Chaukhamba Series office Varanasi 2012 Sutrasthana 2/36 19.

6. Shri Bhav Mishra, Bhavprakash Nighantu purvakhandaChaukhamba Sanskrit SansthanVaranasi, India 11 edition 133-134.

7. Sharma Priyvat Sharma Guruprasad Kaiyadev Nighantu,

PathyapathyaVibodhakaViharavargaChaukhamba Publication Varanasi 200978.497.

8. Sharma Priyvat Sharma Guruprasad Kaiyadev Nighantu,
PathyapathyaVibodhakaViharavargaChaukhamba Publication Varanasi 2009 83-83. 498.

9. Sharma Priyvat Sharma Guruprasad Kaiyadev Nighantu,

PathyapathyaVibodhakaViharavargaChaukhamba Publication Varanasi 200986.498.

10. Sharma Priyvat Sharma Guruprasad Kaiyadev Nighantu,

PathyapathyaVibodhakaViharavargaChaukhamba Publication Varanasi 200987.498.

11. Sharma Priyvat Sharma Guruprasad Kaiyadev Nighantu,

PathyapathyaVibodhakaViharavargaChaukhamba Publication Varanasi 200991.499.

12. Sharma Priyvat Sharma Guruprasad Kaiyadev Nighantu,

PathyapathyaVibodhakaViharavargaChaukhamba Publication Varanasi 200990.499.

13. Sharma Shivprasad. AshtangSanghrahaSutrasthanChaukhamba Sanskrit Series Office Varanasi 2012.19

14. Vaidya Shri Lakshmipati Shastri. Yogratnakar Samhita Vidyotini tika. Chaukhamba Publication Varanasi Nitya pravriti prakar 186. 74.

15. Vaidya Shri Lakshmipati Shastri. Yogratnakar Samhita Vidyotini tika. Chaukhamba Publication Varanasi Nitya pravriti prakar 187. 74.

16. Vaidya Shri Lakshmipati Shastri. Yogratnakar Samhita Vidyotini tika. Chaukhamba Publication Varanasi Nitya pravriti prakar 188. 74.

17. Vaidya Shri Lakshmipati Shastri. Yogratnakar Samhita Vidyotini tika. Chaukhamba Publication Varanasi Nitya pravriti prakar 172. 73 .

18. Garg A, Chaturvedi P, Mishra A, Datta S A review on harmful effects of pan masala.

19. Shri Bhav Mishra, Bhavprakash Nighantu purvakhandaGuduchyadivargaChaukhamba Sanskrit SansthanVaranasi, India 11 edition.

20. Ambika Dutt Shastri Sushrut Samhita vol 1, reprint 1994 Chaukhamba publication, Varanasi, India.

\section{Source of Support: Nil \\ Conflict of Interest: None Declared}

How to cite this URL: Shradha Venkatrao Joshi \& Shital O. Chavan: Focus On Health Benefits Of Tambul Sevan Vidhi As Dincharya Upakrama - A Literature Review. International Ayurvedic Medical Journal \{online\} 2021 \{cited December 2021\} Available from: http://www.iamj.in/posts/images/upload/3034_3037.pdf 